\title{
ADVANCES IN DRAINAGE: SELECTED WORKS FROM THE TENTH INTERNATIONAL DRAINAGE SYMPOSIUM
}

\author{
J. S. Strock, C. H. Hay, M. J. Helmers, K. A. Nelson, G. R. Sands, \\ R. W. Skaggs, K. R. Douglas-Mankin
}

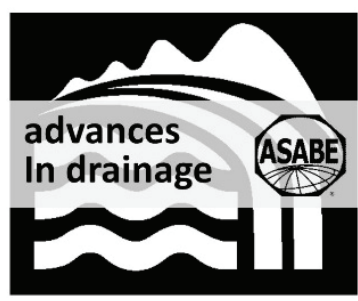

ABSTRACT. This article introduces a special collection of fourteen articles accepted from among the 140 technical presentations, posters, and meeting papers presented at the 10th International ASABE Drainage Symposium. The symposium continued in the tradition of previous symposia that began in 1965 as a forum for presenting and assessing the progress of drainage research and implementation throughout the world. The articles in this collection address a wide range of topics grouped into five broad categories: (1) crop response, (2) design and management, (3) hydrology and scale, (4) modeling, and (5) water quality. The collection provides valuable information for scientists, engineers, planners, and others working on crop production, water quality, and water quantity issues affected by agricultural drainage. The collection also provides perspectives on the challenges of increasing agricultural production in a changing climate, with ever-greater attention to water quality and quantity concerns that will require integrated technical, economic, and social solutions.

$\mathrm{T}$ his article introduces the "Advances in Drainage" collection published in Transactions of the ASABE and Applied Engineering in Agriculture and comprised of 14 peer-reviewed articles resulting from the 10th International Drainage Symposium held in Minneapolis, Minnesota, on 6-9 September 2016. This introduction provides a perspective on the articles from five categories: crop response, design and management, hydrology, modeling, and water quality. The goal of the collection is to highlight recent advances in science and engineering research and their applications to address drainage water management issues relevant to crop production and water quality.

The concept of excess water in the root zone encompasses a range of soil water conditions. The severity and duration of excess water in the root zone can affect soil physical, chemical, and biological properties as well as plant growth and development. Temporary waterlogging of the soil can

Submitted for review in October 2017 as manuscript number NRES 12668; approved for publication as part of the "Advances in Drainage: Selected Works from the 10th International Drainage Symposium" collection by the Natural Resources \& Environmental Systems Community of ASABE in November 2017.

The authors are Jeffrey S. Strock, Professor, Southwest Research and Outreach Center, University of Minnesota, Lamberton, Minnesota; Christopher H. Hay, Senior Environmental Scientist, Iowa Soybean Association, Ankeny, Iowa; Matthew J. Helmers, Dean's Professor, Department of Agricultural and Biosystems Engineering, Iowa State University, Ames, Iowa; Kelly A. Nelson, Professor, Greenley Research Center, University of Missouri, Novelty, Missouri; Gary R. Sands, Professor, Department of Biosystems and Agricultural Engineering, University of Minnesota, St. Paul, Minnesota; R. Wayne Skaggs, Professor Emeritus, Department of Biological and Agricultural Engineering, North Carolina State University, Raleigh, North Carolina; Kyle R. DouglasMankin, Supervisory Research Hydrologist, U.S. Geological Survey, Albuquerque, New Mexico. Corresponding author: Jeffrey S. Strock, Southwest Research and Outreach Center, 23669 130th St., Lamberton, MN 56152; phone: 507-752-5064; e-mail: jstrock@umn.edu. influence gas exchange between soil and the atmosphere, deplete soil oxygen, reduce soil temperature, damage soil structure, decrease the oxidation-reduction potential of the soil, affect the $\mathrm{pH}$ and chemical equilibria of the soil, stimulate denitrification loss of nitrogen $(\mathrm{N})$, affect the speciation and availability of plant nutrients, influence disease incidence and severity, and inhibit plant growth and development (Maryam and Nasreen, 2012; Ponnamperuma, 1984; Stolzy and Sojka, 1984).

Land drainage may be advantageous if excess water creates a need for surface drainage due to water ponding on the soil surface or a need for subsurface drainage due to shallow groundwater or soils with low permeability. Surface and subsurface drainage systems have enabled agricultural production on much of the most productive lands in the world. Artificial drainage provides a pathway for excess or drainable water to be removed from the soil. According to data compiled by the International Commission on Irrigation and Drainage (ICID, 2017), the global land area estimated to be artificially drained is about 194 Mha.

Advances in science and engineering have resulted in the evaluation of the effects of drainage system design, management, and performance simultaneously with the evaluation of agronomic practices on crop production and water quality. While water and nutrients are essential inputs for profitable crop production in certain regions, previous research (Randall and Mulla, 2001; Dinnes et al., 2002; King et al., 2015) has shown that subsurface drainage systems deliver nitrate$\mathrm{N}$ and dissolved reactive phosphorus $(\mathrm{P})$ to surface waters and thereby can contribute to water quality degradation.

\section{History OF ASABE DRAINAGE SYMPOSIA, 1965-2016}

The first drainage symposium was held in 1965 prior to 
Table 1. Summary of ASABE drainage symposia between 1965 and 2016, including location, symposia chair, number of papers, proceedings editor, keynote speakers, and selected themes and highlights.

\begin{tabular}{|c|c|c|c|c|c|c|}
\hline \multicolumn{7}{|c|}{ ASABE Drainage Symposia } \\
\hline Year & Location & Chair & $\begin{array}{l}\text { No. of } \\
\text { Papers }\end{array}$ & $\begin{array}{l}\text { Proceedings } \\
\text { Editor }\end{array}$ & $\begin{array}{l}\text { Keynote } \\
\text { Speakers }\end{array}$ & Themes and Highlights \\
\hline 1965 & Chicago & J. van Schilfgaarde & 28 & - & H. W. Hannah & $\begin{array}{l}\text { "Drainage for efficient crop production." ASAE's first spe- } \\
\text { cialty conference. Sessions on drainage requirements for } \\
\text { plants, soil properties, methods and design criteria. }\end{array}$ \\
\hline 1971 & Chicago & $\begin{array}{l}\text { G. Schwab and } \\
\text { R. Reeves }\end{array}$ & 16 & J. Fouss & J. van Schilfgaarde & $\begin{array}{l}\text { "Drainage equipment and installation." Development of } \\
\text { corrugated plastic drains, drainage plow, laser grade con- } \\
\text { trol; exciting time for drain equipment and technology. }\end{array}$ \\
\hline 1976 & Chicago & R. W. Skaggs & 31 & G. J. Hoffman & G. R. Bagley & $\begin{array}{l}\text { "Drainage for crop production and the environment." First } \\
\text { symposium sessions on water quality, salinity control, and } \\
\text { simulation models for drainage systems. }\end{array}$ \\
\hline 1982 & Chicago & L. Willardson & 23 & G. Kriz & J. van Schilfgaarde & $\begin{array}{l}\text { "Advances in drainage." Sessions on design, construction } \\
\text { techniques, and heavy soils. Proceedings dedicated to } \\
\text { James N. Luthin for his contributions to drainage. }\end{array}$ \\
\hline 1987 & Chicago & N. Fausey & 52 & W. R. Johnston & $\begin{array}{l}\text { R. W. Skaggs, } \\
\text { L. S. Willardson, } \\
\text { and J. W. Gilliam }\end{array}$ & $\begin{array}{l}\text { "Drainage design and management." Sessions on crop re- } \\
\text { sponse to drainage, impacts on water quality, controlled } \\
\text { drainage, drainage envelopes, and performance of mole } \\
\text { drains. }\end{array}$ \\
\hline 1992 & Nashville & J. Fouss & 65 & $\begin{array}{l}\text { R. Bengston } \\
\text { and C. Carter }\end{array}$ & $\begin{array}{l}\text { R. W. Skaggs } \\
\text { and D. A. Bucks }\end{array}$ & $\begin{array}{l}\text { "Drainage and water table control." First international sym- } \\
\text { posium; sessions on environmental impacts, water quality, } \\
\text { wetlands, salinity control, and drainage modeling. }\end{array}$ \\
\hline 1998 & Orlando & R. Evans & 86 & L. Brown & G. Spoor & $\begin{array}{l}\text { "Drainage in the } 21 \text { st century." Study tours preceded and } \\
\text { followed the symposium. Proceedings dedicated to Jan van } \\
\text { Schilfgaarde for contributions to drainage. }\end{array}$ \\
\hline 2004 & Sacramento & C. Madramootoo & 48 & R. Cooke & $\begin{array}{l}\text { N. Fausey and } \\
\text { R. W. Skaggs }\end{array}$ & $\begin{array}{l}\text { "Drainage VIII." Sessions on drainage of irrigated lands, } \\
\text { water quality, application of models, water table manage- } \\
\text { ment, and a special "Drainage management for the Mid- } \\
\text { west U.S." session. }\end{array}$ \\
\hline 2010 & Quebec City & A. Madani & 77 & G. M. Chescheir & A. Musy & $\begin{array}{l}\text { "Ninth international drainage symposium." Presentations } \\
\text { from } 22 \text { countries on drainage topics. Tribute presented to } \\
\text { R. Wayne Skaggs for contributions to drainage. }\end{array}$ \\
\hline 2016 & Minneapolis & $\begin{array}{l}\text { J. Frankenberger } \\
\text { and G. Sands }\end{array}$ & 134 & J. S. Strock & $\begin{array}{l}\text { R. W. Skaggs and } \\
\text { H. Ritzema }\end{array}$ & $\begin{array}{l}\text { "Tenth international drainage symposium." More than } 225 \\
\text { attendees for two days of technical sessions, a day of field } \\
\text { tours, and a dinner cruise on the Mississippi River. }\end{array}$ \\
\hline
\end{tabular}

the American Society of Agricultural Engineers (ASAE) annual winter meeting in Chicago. It was called a drainage conference and was the first specialty conference sponsored by ASAE (now the American Society of Agricultural and Biological Engineers, ASABE). Succeeding drainage symposia were held every five or six years over the next 50 years (table 1). There was international participation in the symposia from the beginning, and the name was changed to International Drainage Symposium in 1992. Recognizing that over $25 \%$ of cropland in the U.S. and Canada and more than $35 \%$ globally required improved drainage for efficient crop production, the purpose of the symposia was to provide a forum for discussion and review of progress on the science and application of agricultural drainage. The proceedings of the symposia provide a valuable record of that progress, but the actual products and benefits were far greater than simply a published record. The symposia provided a forum for the presentation of concepts and work in progress, as well as results of completed projects. These early presentations and discussions stimulated interaction and cooperative work among researchers, agencies, and contractors, ultimately increasing the rate of progress toward improved drainage and agricultural water management. A brief overview of the primary themes of each symposium is discussed below.

\section{5: Drainage for EfFicient Crop Production}

At the first drainage symposium, there were sessions on drainage requirements for plants, soil properties, drainage materials and methods, and drainage design criteria. While drainage theory was well developed by 1965 , and progress on current research to determine plant response to waterlogging was reported, there was no objective means of quantifying the effect of drainage design on crop yields and profits. This emerged as a clear goal for future drainage research. Progress on the use of plastic pipe for drains and formed-inplace plastic "zipper" drain tubes as alternatives for traditional clay and concrete tile was reported at this first symposium. It turned out that drainage technology was on the cusp of a profound and rapid expansion, as would be obvious by the time of the second drainage symposium in 1971.

\section{1: DRAINAGE EQUIPMENT AND INSTALLATION}

Development of new materials and methods (i.e., corrugated plastic pipe, fabric filters, drain tube plow, laser grade control) virtually exploded from 1965 to 1975 . By 1971, corrugated plastic drain pipe was being used in about $20 \%$ of new farm drainage, with estimates that it would exceed $70 \%$ by 1975 . New machines, including trenchless plows, had been developed, and laser grade control had already become the standard for maintaining grades of subsurface drains. Laser grade control would quickly become a pervasive technology used in other construction applications, but its first application was for precise grade control of subsurface drains. Symposium sessions on the characteristics of and methods for testing drainage materials, development of specifications for drainage materials, and equipment and installation meth- 
ods were attended by more than 260 engineers, researchers, manufactures, contractors, and government agencies.

\section{6: Drainage For CRop Production ANd THE ENVIRONMENT}

This symposium included seven technical sessions and an informal "New ideas from industry" session. This was the first drainage symposium with sessions on drainage water quality, a subject that would play a dominant role in future symposia. A session on models for drainage design and evaluation included a paper on the use of the first version of the computer simulation model DRAINMOD to analyze the performance of drainage and drainage water management (controlled drainage and subirrigation) systems.

\section{2: ADVANCES IN DRAINAGE}

The 1982 symposium included sessions on drainage design, construction techniques, and heavy soils, and the proceedings were dedicated to James N. Luthin for his contributions to drainage theory and practice. The program included several papers and detailed discussions on methods to determine the need for drainage envelopes, testing of envelopes, and drainage of heavy clay and alluvial soils. DRAINMOD had been extended to predict crop yields, and a paper was presented on its application to predict the effects of drain spacing and surface drainage intensity on yields and profits. Reports on further extensions of the model to predict losses of $\mathrm{N}$ in drainage water, soil salinity, along with numerous papers on testing and application of the model and its modifications, would be presented and published in the proceedings of future symposia. Beginning in 1992, workshops on the theory and application of DRAINMOD have been offered at every drainage symposium to date.

\section{7: Drainage Design ANd Management}

The 1980s were a difficult period for agricultural drainage due to economic crises impacting global agricultural markets and environmental issues related to wetlands. Recognition of the ecological and environmental value of wetlands and concern that long-term government policies had encouraged conversion of wetlands to agricultural production resulted in substantial reduction in government support for drainage. USDA Agricultural Research Service (USDA-ARS) units and university positions that focused on drainage research were dramatically reduced, as was USDA Natural Resources Conservation Service (USDA-NRCS) assistance for designing and installing farm drainage. These actions failed to recognize the importance of drained lands to our cropland base. New challenges would eventually demand increased research and development on drainage issues. Despite the downturn in the drainage industry, the 1987 drainage symposium was well attended, with a record number of papers on crop response to drainage, soil properties, drainage criteria, impacts on water quality, controlled drainage, drainage envelopes, machinery development, and performance of mole drains.

\section{2: Drainage AND WATER TABle ControL}

The 1992 drainage symposium was the first one conducted as an international symposium, with presenters from
12 countries. Session topics included environmental impacts, wetlands, sustainability, drainage modeling, drainage as a part of total water management, and salinity control/water quality. The keynote paper noted that the impacts of design and management on drainage water quality were reasonably well understood and proposed that minimizing such impacts should be considered at the design stage. The importance of water quality and environmental impacts of agricultural drainage is demonstrated by the fact that $34 \%$ of the papers at this symposium were on these subjects, and this percentage steadily increased to $59 \%$ by the 2016 symposium.

\section{8: DRAinage IN THE 21ST CENTURY}

At the time of this symposium, the cumulative impact of drainage on a watershed scale was a high-priority issue. The program included presentation of numerous studies on holistic watershed-scale models to evaluate such impacts. This largest drainage symposium program to date included sessions on water quality and environment (3 sessions), salinity (2 sessions), modeling (2 sessions), and drainage water management. There were optional study tours and a 2.5 day agricultural water management/wetlands tour following the meeting. The proceedings were dedicated to Jan van Schilfgaarde for outstanding contributions to the science and application of drainage.

\section{4: DRAINAGE VIII}

Sacramento, California, was chosen for the eighth symposium to promote presentations and discussion of drainage of irrigated lands and salinity control. An excellent session on this subject was held on the first day of the symposium. Other sessions included drainage management, drainage and water quality, drainage performance, tools and models for design, installation and infrastructure, and drainage and the landscape. A special "Drainage management for the Midwest U.S." session was organized by members of the Agricultural Drainage Management Systems (ADMS) task force. Half of the symposium papers involved drainage water quality. Most involved N, with several papers on the effects of drainage design and controlled drainage on $\mathrm{N}$ losses. A paper on the development of controlled drainage as a state and federal sponsored best management practice (BMP) to reduce $\mathrm{N}$ losses from 162,000 ha of cropland in North Carolina was presented. Other papers discussed the effectiveness of bioreactors, denitrification walls, cover crops, and wetlands for reducing $\mathrm{N}$ losses.

\section{0: NINTH INTERNATIONAL DRAINAGE SYMPOSIUM}

This symposium was held jointly with the International Commission of Agricultural and Biosystems Engineering (CIGR) and the Canadian Society of Bioengineering (CSBE/SCGAB). There were 77 presentations from 22 countries in 12 technical sessions on drainage and water quality, drainage models, salinity, drainage water management, drainage envelopes, and drainage of forested lands. Several papers, about $19 \%$ of the total, involved the application and testing of models, many of which are still in use today (Moriasi et al., 2012), including SWATR-SWAP (Soil-Water-Atmosphere-Plant) (Kroes et al., 2017), 
RZWQM (Ma et al., 2012), HYDRUS (Šimůnek et al., 2012), MIKE-SHE (Jaber and Shukla, 2012), ADAPT (Gowda et al., 2012), VS2DT (Healy and Essaid, 2012), SWAT (Arnold et al., 2012), and DRAINMOD (Skaggs et al., 2012). The program was especially rich on the subject of drainage water quality, with papers on the effectiveness of saturated riparian buffers, bioreactors, drainage water management, shallow drains, and wetlands. Over $50 \%$ of the presentations involved drainage water quality. At the end of the symposium, organizers presented a tribute to R. Wayne Skaggs for "Outstanding contributions to agricultural drainage and water management."

\section{6: Tenth InTERNATIONAL DRAINAGE SyMPOSIUM}

The 2016 symposium was held in Minneapolis, Minnesota, and included 134 technical presentations addressing opportunities and challenges for agricultural production on the world's poorly drained soils and landscapes. The technical presentations covered topics including water quality, monitoring and measurement, design and policy, and modeling. More than 225 attendees attended two days of technical presentations, a poster session, a day of field tours, and a dinner cruise on the Mississippi River. The opening session keynote address was given by R. Wayne Skaggs, who summarized previous drainage symposia and highlighted advances in drainage science and practice. The closing session keynote address was given by Henk Ritzema, who shared a vision of future challenges and opportunities for engineers, researchers, manufacturers, contractors, and government agencies.

A review of the proceedings of the ten ASABE-sponsored drainage symposia since 1965 reveals a record of tremendous advances in drainage theory, technology, and practice over the past 50 years. We have achieved many of the goals that drainage researchers and practitioners sought for nearly 100 years before the first symposium in 1965 . There have been orders-of-magnitude improvements in drainage materials, installation equipment, and methods. We can now quantitatively describe the performance of drainage systems on a temporal basis and predict the effects of drainage design and management on yields and profits. We can also predict the effects of design and management on $\mathrm{N}$ losses, and we are making progress on $\mathrm{P}$ losses. The models are not perfect, nor easy to use, but they will be improved with time. We have new devices to manage drainage rates with real potential for remote control and data acquisition. These advances are documented in the proceedings of the symposia. While our understanding of the real impacts, benefits, and costs of drainage is much improved, many challenges remain, and new ones will be identified as scientific and engineering knowledge progresses.

Despite advances in science and engineering, drainage has been and will continue to be an essential component of agricultural production. As the need grows for increased food production on limited land resources, coupled with achieving environmental quality goals, the need for sound drainage research will continue to be important (Christianson and Harmel, 2015a). The following sections summarize the fourteen articles in the "Advances in Drainage" collection.

\section{CROP Response}

Artificial drainage systems are critical for resilient crop production systems. Subsurface drainage systems are used to increase aeration and workability of the soil, allow for timely field operations, and increase yields. Depending on the landscape, availability of water, and soil properties, subsurface drainage systems can also be used to supply water to the crop through subirrigation, which can reduce loss of water due to evaporation and runoff compared to surface-applied irrigation systems. Differences in crop responses have been evaluated using direct measurements of crop yields (Nelson, 2017). Increased drainage intensity may be required for water removal or recommended to improve water distribution for subirrigation; however, increased drainage intensity may also affect vegetation production during dry summer months. Research evaluating crop response to drainage systems is the basis for establishing cost-effective drainage or drainage plus subirrigation systems and provides recommendations on drainage intensity.

Claypan soils typically have an impermeable clay layer 45 to $60 \mathrm{~cm}$ below the soil surface. Crops experience a perched water table in the spring and fall, while drought conditions may limit crop production through the summer months. Soybean grain yield variability for drainage only (DO) and drainage plus subirrigation (DSI) was evaluated above the subsurface drain tile for two drain tile spacings over 30-year cultivar management systems (Nelson, 2017). Grain yields were greater with DO and DSI than with the non-drained control. Yield variability was affected by the environment and distance from the subsurface drain tile, which indicated that increased intensity of drainage was needed to decrease yield variability of DSI systems in a claypan soil.

\section{DESIGN AND MANAGEMENT}

The design and management of subsurface agricultural drainage systems have never been more challenging due to the coupling of multiple environmental objectives with traditional agricultural productivity and profitability objectives, nor were drainage design and management simple endeavors when agricultural productivity was the primary objective. Skaggs (2017) asserted that some uniformity and consistency in describing and reporting drainage system capacity would make for more feasible comparisons among different drainage studies. The author also suggested that a minimum of three measures be used to describe drainage system capacity because they operate together to affect system performance: drainage intensity (DI, the drainage rate when the water table midway between parallel drains is coincident with the surface), the Kirkham coefficient (KC, the steady subsurface drainage rate corresponding to a saturated profile with a ponded surface), and the drainage coefficient (DC, the hydraulic capacity of the system outlet). Skaggs (2017) presented examples of how water table drawdown is affected by different combinations of these measures, hence the argument for including multiple hydraulic performance measures in reporting drainage research data.

The design of drainage systems sometimes includes surface ditches, which typically serve as the outlet infrastruc- 
ture for subsurface drainage systems. Avilés et al. (2018) sought to identify parameters important in the prediction of erodibility and stability of agricultural drainage ditches to improve ditch design. Their work, using field observation and modeling, found that both hydraulic loading and soil structural and vegetative characteristics were necessary to explain the risk of ditch bank failure.

Salinity control is an important design and performance objective for many drainage systems throughout the world, and much has been published on the efficacy of subsurface drainage systems in mitigating salinity stress in the crop root zone. Steppuhn and McArthur (2017) presented novel ways of garnering water for leaching salts from artificially drained soils in the semi-arid region of Saskatchewan. In this region, where natural precipitation is insufficient for satisfactory leaching of salts, the authors investigated the feasibility of using snowmelt from captured windborne snow and irrigation from shallow groundwater to augment natural leaching of salts. The authors concluded that snow capture and management can increase the water available to leach salts, reduce soil salinity levels, and significantly increase small grain yields. The authors performed a one-time replicated demonstration of irrigation with shallow groundwater prior to seeding alfalfa to reduce soil salinity and improve seedling emergence rates. Significant alfalfa emergence rate increases were observed in the irrigated plots.

There has been an expansion of subsurface drainage in the Red River Valley, located between Minnesota and North Dakota with flow contribution into Manitoba, Canada. Subirrigation through these drainage systems was evaluated for its performance by measuring soil water storage in the root zone at three site-years in Minnesota and North Dakota (Jia et al., 2017). Water application efficiency and uniformity coefficient evaluation showed improved performance of subirrigation compared to surface irrigation due to reduced water loss, but water uniformity in the soil was less than with surface irrigation systems. Improvement of water application uniformity was discussed.

\section{HYDROLOGY AND SCALE}

Alterations of land use and management for agriculture have been implicated in surface and groundwater quality and quantity concerns. The processes and mechanisms that control the volume and quality of drainage water leaving agricultural land are very complex. Stormwater retention areas receiving subsurface drainage from vegetative production in Florida were proven successful in reducing downstream $\mathrm{N}$ loads through both denitrification and water retention, and that retention could be enhanced through harvesting of biomass (Shukla et al., 2018). This work also evaluated the economic feasibility of harvesting biomass from the stormwater retention area to enhance $\mathrm{N}$ retention and then composting the biomass to be returned to the agricultural land. Despite these systems being relatively costly, this work found economic feasibility when considering the biomass value from the system and inclusion of a state incentive payment program for environmental services. Overall, this work highlighted the benefits of stormwater retention areas and indi- cated that considering a co-benefit, such as biomass production from these systems, could improve their feasibility for farmers. This work also highlighted the need to understand the hydrology of the systems and controlling factors for $\mathrm{N}$ retention or removal under a variety of hydrologic conditions.

During the past several decades, there have been changes in land use and land cover through increased agricultural intensification and increased drainage intensity, coupled with increasing precipitation trends (Sinha et al., 2017). Gupta et al. (2018) analyzed streamflow data from Minnesota and Iowa to assess the role of precipitation in increasing streamflow. Specifically, this analysis explored the role of soil storage and soil wetness on streamflow and baseflow, along with evaluating the climate, land use, and land cover changes at both monthly and daily scales. This study found that increases in streamflow and baseflow in the upper Midwestern U.S. are mainly due to increased precipitation, not only in any given year but also in the preceding two to three years. Increases in preceding years' precipitation increases the soil wetness and soil water storage, increasing the quantity and rate of flow for subsequent precipitation events. This information is important for assessing potential impacts of future precipitation patterns on the hydrology of the upper Midwestern U.S.

\section{Modeling}

The use of drainage models continues to evolve and expand to further refine drainage system design and evaluate alternative designs for enhanced crop productivity and reduced environmental impacts. The articles in this collection include modeling studies of surface drainage and BMPs, combined mole and tile drainage systems, and controlled and shallow drainage systems.

Webber et al. (2018) used geographic information system (GIS) hydrologic modeling functions and geospatial map comparison analysis procedures to evaluate the accuracy of simulated surface drainage flow paths relative to groundtruthed field observations. Their study showed that using a higher-resolution LiDAR digital elevation map (DEM) more accurately simulated surface flow paths than using a $30 \mathrm{~m}$ USGS DEM, which has typically been used for best management practice placement. These results point to opportunities for more accurately siting and designing vegetated filter strip buffers for more effective nonpoint-source pollution reduction.

Tuohy et al. (2018) used the SEEP/W model (GEOSLOPE, 2012) to evaluate alternative designs for combined mole drain and subsurface tile drainage systems. In fine-texture, low-permeability soils, subsurface tile-only drainage systems may not be adequate for controlling high water table conditions. The network of channels and subsoil cracks created with a mole plow convey excess water more rapidly to the subsurface tile drainage system. The results of this study indicate that systems that combine mole drainage with subsurface drainage are more effective at removing excess water from low-permeability soils. The improvement in saturated hydraulic conductivity created by mole drains appears to di- 
rectly correspond to better performance of the combined drainage system.

Craft et al. (2018) used RZWQM (Ma et al., 2012) to examine the impacts of controlled drainage and shallow drainage on $\mathrm{N}$ loads from subsurface drainage systems in southeast Iowa for a nine-year period between 2007 and 2015. Controlled drainage and shallow drainage reduced $\mathrm{N}$ loads by $26 \%$ and $40 \%$, respectively. Shallow drainage was more consistent in reducing $\mathrm{N}$ loads, and controlled drainage was ineffective at reducing $\mathrm{N}$ loads during the critical spring period.

\section{WATER QUALITY}

Surface drainage and subsurface drainage have been and will continue to be necessary components of water and soil management. While the benefits of drainage are numerous, we cannot ignore the potential adverse effects of drainage on the environment, specifically on water quality (Christianson and Harmel, 2015a, 2015b; Christianson et al., 2016). Our challenge, which was the challenge of our predecessors and will likely be a challenge for our successors, is to achieve a balance between satisfying the need for a safe and abundant food supply while protecting natural resources.

Povilaitis et al. (2018) evaluated multiple strategies, including field and laboratory experiments, to investigate drainage effluent reductions of inorganic $\mathrm{N}$ and total $\mathrm{P}$ in Lithuania. Controlled drainage as an example of an in-field water management practice to reduce nutrient loss was compared with conventional drainage. Laboratory and edge-offield bioreactors, with various carbon sources to stimulate denitrification plus lime to sorb $\mathrm{P}$, were used to investigate the magnitudes of $\mathrm{N}$ and $\mathrm{P}$ removal from drainage water. Finally, in-ditch evaluation of a filter well for $\mathrm{N}$ and $\mathrm{P}$ removal using three $\mathrm{N}$ and three $\mathrm{P}$ filter materials was performed to measure $\mathrm{N}$ and $\mathrm{P}$ removal rates and removal efficiencies from ditch water. The in-field research showed reductions of $\mathrm{N}$ and $\mathrm{P}$ from controlled drainage and attributed the reductions to reduced drainage outflow from the controlled drainage system compared to the conventional system. The edgeof-field research gave mixed results. All materials investigated resulted in reduced $\mathrm{N}$ concentrations in the drainage water, whereas lime was the only material that reduced total $\mathrm{P}$ concentrations. The in-ditch filter experiment demonstrated that all the materials investigated showed the ability to remove $\mathrm{P}$ from drainage water.

Pease et al. (2018) characterized landscape, weather, and field management factors, individually and collectively, and their impacts on nitrate- $\mathrm{N}$ and soluble $\mathrm{P}$ concentrations in the Western Lake Erie Basin watershed. They found that landscape factors, including soil texture, drain spacing, slope, and soil test $\mathrm{P}$, plus their interactions with other factors, affected nitrate-N and soluble $\mathrm{P}$ concentrations. Weather effects on nitrate- $\mathrm{N}$ and soluble $\mathrm{P}$ concentrations were strongly influenced by season and rainfall, with nitrate-N concentration higher in spring and soluble $\mathrm{P}$ concentration higher in summer. The response of nitrate- $\mathrm{N}$ and soluble $\mathrm{P}$ concentrations to rainfall suggested that the major mechanism of $\mathrm{P}$ loss was preferential flow, whereas the major pathway for ni-
trate-N loss was through the soil matrix. Finally, the researchers observed that field management practices, specifically date of fertilizer application and fertilizer application rate, were strong predictors of nitrate- $\mathrm{N}$ and soluble $\mathrm{P}$ concentration, respectively.

A nine-year replicated field experiment in eastern North Carolina demonstrated that drain flow from controlled drainage was significantly reduced compared to conventional free drainage (Poole et al., 2018). The response of nitrate- $\mathrm{N}$ concentration to controlled drainage resulted in an increase in flow-weighted mean nitrate concentrations compared to conventional free drainage. Over the nine-year experiment, controlled drainage resulted in a significant reduction in nitrate-N load compared to conventional free drainage. The reduction in nitrate- $\mathrm{N}$ load from the controlled drainage treatment was equivalent to the observed increase in grain $\mathrm{N}$ uptake by the crops grown with controlled drainage.

\section{Summary And Conclusions}

The practice of land drainage and the management of agricultural drainage water have undergone extraordinary advances since the middle of the 20th century. Global population growth is leading to global intensification of agricultural production in order to ensure food security, availability, and accessibility. Climate variability and change coupled with land use change place stress on land and water resources. Opportunities for sustainable intensification of agricultural production, which include drainage water management, have never been greater. Perhaps the greatest challenge for drainage system design and management is to reduce downstream impacts due to losses of $\mathrm{N}$ and $\mathrm{P}$ in drainage outflows. The water quality consequences are severe and, without significant changes, will likely get worse. Solutions that would greatly reduce the problem have been researched and presented at the ASABE drainage symposia, but most of them will not be applied on a scale necessary to adequately treat the issue without better incentives to encourage their adoption. As with many water quality issues, the basic problem is that the benefits of applying measures to reduce nutrient losses and improve drainage water quality would be enjoyed and appreciated by society at large, but the costs of applying the practices to provide these benefits would be borne by the producers. Future research must consider drainage system design and management, agronomic management practices, and the role of government and market forces in implementing technical solutions at the scale needed to make a measurable impact. Future emphasis on management of drainage systems should focus on achieving an acceptable balance between agricultural productivity, conservation, and environmental quality.

\section{ACKNOWLEDGEMENTS}

This article is one of fourteen articles in the "Advances in Drainage" collection in this issue of Transactions of the $A S A B E$ and the previous issue of Applied Engineering in Agriculture. The authors wish to thank the ASABE publications staff, associate editors, and reviewers for their contributions to and timely management of the review process, and 
the authors and co-authors of articles in this collection for their valuable contributions to the research literature.

\section{REFERENCES}

Arnold, J. G., Moriasi, D. N., Gassman, P. W., Abbaspour, K. C., White, M. J., Srinivasan, R., ... Jha, M. K. (2012). Swat: Model use, calibration, and validation. Trans. ASABE, 55(4), 14911508. https://doi.org/10.13031/2013.42256

Avilés, D., Wesstrom, I., \& Joel, A. (2018). Status assessment of agricultural drainage ditches. Trans. ASABE, 61(1), 263-271. https://doi.org/10.13031/trans.12307

Christianson, L. E., \& Harmel, R. D. (2015a). The MANAGE Drain Load database: Review and compilation of more than fifty years of North American drainage nutrient studies. Agric. Water Mgmt., 159, 277-289. https://doi.org/10.1016/j.agwat.2015.06.021

Christianson, L. E., \& Harmel, R. D. (2015b). 4R water quality impacts: An assessment and synthesis of forty years of drainage nitrogen losses. J. Environ. Qual., 44(6), 1852-1860. https://doi.org/10.2134/jeq2015.03.0170

Christianson, L. E., Harmel, R. D., Smith, D., Williams, M. R., \& King, K. (2016). Assessment and synthesis of 50 years of published drainage phosphorus losses. J. Environ. Qual., 45(5), 1467-1477. https://doi.org/10.2134/jeq2015.12.0593

Craft, K. J., Helmers, M. J., Malone, R. W., Pederson, C. H., \& Schott, L. R. (2018). Effects of subsurface drainage systems on water and nitrogen footprints simulated with RZWQM2. Trans. ASABE, 61(1), 245-261. https://doi.org/10.13031/trans.12300

Dinnes, D. L., Karlen, D. L., Jaynes, D. B., Kaspar, T. C., Hatfield, J. L., Colvin, T. S., \& Cambardella, C. A. (2002). Nitrogen management strategies to reduce nitrate leaching in tile-drained midwestern soils. Agron. J., 94(1), 153-171. https://doi.org/10.2134/agronj2002.1530

GEO-SLOPE. (2012). Seepage modeling with SEEP/W. Calgary, Alberta, Canada: GEO-SLOPE International. Retrieved from http://downloads.geo-

slope.com/geostudioresources/8/0/6/books/seep\%20modeling.pd $\mathrm{f} ? \mathrm{v}=8 \cdot 0.7 .6129$

Gowda, P. H., Mulla, D. J., Desmond, E. D., Ward, A. D., \& Moriasi, D. N. (2012). ADAPT: Model use, calibration, and validation. Trans. ASABE, 55(4), 1345-1352. https://doi.org/10.13031/2013.42246

Gupta, S. C., Baeumler, N. W., Kessler, A. C., Brown, M. K., Schuh, W. M., \& Wolf, K. A. (2018). Increased precipitation as the main driver of increased streamflow in tile-drained watersheds of the upper Midwestern U.S. Trans. ASABE, 61(1), 207-222. https://doi.org/10.13031/trans. 12279

Healy, R. W., \& Essaid, H. I. (2012). VS2DI: Model use, calibration, and validation. Trans. ASABE, 55(4), 1249-1260. https://doi.org/10.13031/2013.42238

ICID. (2017). World drained area. International Commission on Irrigation and Drainage. Retrieved from http://www.icid.org/database icid.html

Jaber, F. H., \& Shukla, S. (2012). MIKE SHE: Model use, calibration, and validation. Trans. ASABE, 55(4), 1479-1489. https://doi.org/10.13031/2013.42255

Jia, X., Scherer, T. F., Steele, D. D., \& DeSutter, T. M. (2017). Subirrigation system performance and evaluation in the Red River Valley of the North. Appl. Eng. Agric., 33(6), 811-818. https://doi.org/10.13031/aea.12286

King, K. W., Williams, M. R., \& Fausey, N. R. (2015). Contributions of systematic tile drainage to watershed-scale phosphorus transport. J. Environ. Qual., 44(2), 486-494. https://doi.org/10.2134/jeq2014.04.0149
Kroes, J. G., van Dam, J. C., Bartholomeus, R. P., Groenendijk, P., Heinen, M., Hendriks, R. F., ... van Walsum, P. E. (2017). SWAP version 4; Theory description and user manual. Report 2780. Wageningen, The Netherlands: Wageningen Environmental Research.

Ma, L., Ahuja, L. R., Nolan, B. T., Malone, R. W., Trout, T. J., \& Qi, Z. (2012). Root zone water quality model (RZWQM2): Model use, calibration, and validation. Trans. ASABE, 55(4), 1425-1446. https://doi.org/10.13031/2013.42252

Maryam, A., \& Nasreen, S. (2012). A review: Water logging effects on morphological, anatomical, physiological and biochemical attributes of food and cash crops. Intl. J. Water Resour. Environ., 2(4), 119-126.

Moriasi, D. N., Wilson, B. N., Douglas-Mankin, K. R., Arnold, J. G., \& Gowda, P. H. (2012). Hydrologic and water quality models: Use, calibration, and validation. Trans. ASABE, 55(4), 1241-1247. https://doi.org/10.13031/2013.42265

Nelson, K. A. (2017). Soybean yield variability of drainage and subirrigation systems in a claypan soil. Appl. Eng. Agric., 33(6), 801-809. https://doi.org/10.13031/aea.12276

Pease, L. A., Fausey, N. R., Martin, J. F., \& Brown, L. C. (2018). Weather, landscape, and management effects on nitrate and soluble phosphorus concentrations in subsurface drainage discharge in the western Lake Erie basin. Trans. ASABE, 61(1), 223-232. https://doi.org/10.13031/trans. 12287

Ponnamperuma, F. N. (1984). Effects of flooding on soils. In T. T. Kozlowski (Ed.), Flooding and plant growth (pp. 9-45). San Francisco, CA: Academic Press. https://doi.org/10.1016/B978-012-424120-6.50007-9

Poole, C. A., Skaggs, R. W., Youssef, M. A., Chescheir, G. M., \& Crozier, C. R.. (2018). Effect of drainage water management on nitrate-nitrogen loss to tile drains in North Carolina. Trans. ASABE, 61(1), 233-244. https://doi.org/10.13031/trans.12296

Povilaitis, A., Rudzianskaitè, A., Misevičienè, S., Gasiūnas, V., Miseckaitè, O., \& Živatkauskienè, I. (2018). Efficiency of drainage practices for improving water quality in Lithuania. Trans. ASABE, 61(1), 179-196. https://doi.org/10.13031/trans.12271

Randall, G. W., \& Mulla, D. J. (2001). Nitrate nitrogen in surface waters as influenced by climatic conditions and agricultural practices. J. Environ. Qual., 30(2), 337-344. https://doi.org/10.2134/jeq2001.302337x

Shukla, A., Shukla, S., \& Hodges, A. W. (2018). Recovering nitrogen from farm-scale drainage: Mechanism and economics. Trans. ASABE, 61(1), 197-206. https://doi.org/10.13031/trans.12277

Šimůnek, J., van Genuchten, M. T., \& Sejna, M. (2012). HYDRUS: Model use, calibration, and validation. Trans. ASABE, 55(4), 1263-1274. https://doi.org/10.13031/2013.42239

Sinha, E., Michalak, A. M., \& Balaji, V. (2017). Eutrophication will increase during the 21 st century as a result of precipitation changes. Science, 357(6349), 405-408.

https://doi.org/10.1126/science.aan2409

Skaggs, R. W. (2017). Coefficients for quantifying subsurface drainage rates. Appl. Eng. Agric., 33(6), 793-799. https://doi.org/10.13031/aea.12302

Skaggs, R. W., Youssef, M. A., \& Chescheir, G. M. (2012). DRAINMOD: Model use, calibration, and validation. Trans. $A S A B E$, 55(4), 1509-1522. https://doi.org/10.13031/2013.42259

Steppuhn, H., \& McArthur, L. J. B. (2017). Enhancing subsurface drainage to control salinity in dryland agriculture. Appl. Eng. Agric, 33(6), 819-824. https://doi.org/10.13031/aea.12252.

Stolzy, L. H., \& Sojka, R. E. (1984). Effects of flooding on plant disease. In T. T. Kozlowski (Ed.), Flooding and plant growth (pp. 221-264). Cambridge, MA: Academic Press. https://doi.org/10.1016/B978-0-12-424120-6.50012-2 
Tuohy, P., O’Loughlin, J., \& Fenton, O. (2018). Modeling performance of a tile drainage system incorporating mole drainage. Trans. ASABE, 61(1), 169-178

https://doi.org/10.13031/trans.12203
Webber, D. F., Bansal, M., Mickelson, S. K., Helmers, M. J., Arora, K., Gelder, B. K., ... Judge, C. J. (2018). Assessing surface flowpath interception by vegetative buffers using ArcGIS hydrologic modeling and geospatial analysis for Rock Creek watershed in central Iowa. Trans. ASABE, 61(1), 273-283. https://doi.org/10.13031/trans.12350 